\title{
Strengthening Institutions and Enterprises of Cooperative and Their Impact on Members' Assets
}

\author{
SRI WIDIYATI SOEMODIPOERO \\ Jurusan Akuntansi, Politeknik Negeri Semarang, Jl.Prof.Sudarto,SH, Tembalang, Semarang \\ email: wiwidsoemodipoero@yahoo.co.id
}

\begin{abstract}
Revitalization of Cooperative interpreted as a series of activities undertaken to reorganize the institutional and strengthen cooperative efforts in accordance with the values and principles of cooperatives. Cooperative serves as a tool to equalize the concentration of control of economic assets so that the weak economy may have opportunities to enhance economic independence. The purpose of this study is to explore the link between the level of member participation and human resource competencies to the strengthening of the institutional and cooperative efforts as well as its impact on member assets. This research used logistic regression analysis and Wilcoxon Signed Rank Test. The results showed that the level of participation of members and managers of Human Resources competencies significantly affect institutional strengthening and cooperative efforts. Different test shows that there is a difference between financial capital and human capital before and after become a member of the cooperative.
\end{abstract}

Keywords: participation, human resources, institutions, businesses, cooperatives

\section{Introduction}

Cooperative is a business entity consisting of person or business entity that aims to improve the welfare of its members. Cooperative is not capital collection, but a collection of "person." Homosocius are social creatures who maintain harmony between the members and work for the common interest. In accordance with the understanding that the cooperative more emphasis on understanding of cooperatism (coorperation based) which will form a force multiplier, to work together in order to achieve efficiency (Sri Edi Swasono: 2012).Cooperative becomes effective means for the country's economic restructuring in the control of economic assets in the community. Cooperative serves as a means to equalize the concentration of control of economic assets so that the weak economy may have a chance to improve their economic independence. Indonesia co operative role is an agent of development for poverty reduction, improve the welfare of members and spread the spirit and soul of cooperatives' role in other business entities.

The existence of Microfinance (microfinance institutions) in developing countries such as Nigeria, India, Bangladesh, Sudan, Addis Ababa-Ethiopia, often associated with low income people. The existence of micro-finance institutions have been able to empower the poor women, in particular, and productive economic activity in general that helps increasing revenue as well as cut the cycle of poverty (Amira Y. Badri: 2013, Omotola Awojobi and Murad Bein: 2011; S.Sarumathi and K. Mohan: 2011). Cooperatives play an important role in the creation of assets through many ways such as savings, credit, and health insurance. Microcredit program is able to strengthen women not only in the economic, but also in the social aspect. Women are able to have their own income, able to contribute to the family finances and is also able to help the education of children. Microfinance institutions in this cooperative is able to develop communities by strengthe ning social capital, economic and social activities (Wilson Majee and Ann Hoyt: 2011).

Studies conducted by Omonona (2011), explains that poverty in rural areas occured

Received: November 12, 2016, Revision: April 12, 2017, Accepted: May 19, 2017

Print ISSN: 0215-8175; Online ISSN: 2303-2499.

Accredited by DIKTI. SK Kemendikbud, No.040/P/2014, valid 18-02-2014 until 18-02-2019, Indexed by DOAJ 
due to the large number of family members, limitations in human assets such as education and skills, limited landholdings, and limited access to information. To overcome poverty, the involvement of microfinance institutions is needed. Microfinance institutions through microcredit along with training related to business skills to develop existing businesses and will help to result a change of life.

While Muhammad Kashif Khan Durrani et al. (2011) proved that microfinance institutions were able to increase the confidence of the poor. Urgent financial problems can be resolved. Microfinance institutions through savings and credit were able to develop the business that creates income generating. Earned income allocated to consumption, investment, pay the installments and to increase production. Strengthening the capacity of individuals and households will result in the increase of wealth which includes a wealth of financial, human capital (education and health improvement), and social capital (sharing of information between members, decision-making ability, enhancement of cooperation).

The existence of cooperatives in Indonesia is still far from societal expectations. This is evident from the contribution of cooperatives to Gross Domestic Product (GDP) which is $2 \%$ while state-owned enterprises is $20 \%$, and the private sector including foreign companies amounted to $78 \%$ (www.suaramerdeka. com); performers of cooperatives have less or even do not understand about the identity of cooperatives, cooperative bad image became the focus of reporting by mass media (Sri Edi Swasono: 2012). Cooperative poor image due to the cooperative human resources that have not been competent, cooperative management which is not working optimally and causes number of cases of corruption in the cooperative (Sukijo: 2008).

The support of cooperatives is still very low related to the reduction of poverty (Johnny W.Situmorang and SaudinSijabat: 2011; Sri Widiyati, 2012). Viewed from the side of the cooperative health, statistical data until the end of the first quarter of 2015 , there are 81 cooperatives in the city of Semarang which have received a cooperative health assessment. Of 81 cooperatives, 42 of them have saving and loan unit, and 39 are saving and loan cooperatives. Among the 39 cooperatives, 6 of them categorized as healthy cooperatives and 33 are categorized fairly healthy Cooperatives (www.dinkop-umkm. jatengprov.go.id). The data above indicates that a majority of the macro performance of cooperatives is still worrying.

The United Nation has set 2012 as the year of the World Cooperative. On that basis, Indonesian government also launched year of 2012 as the revitalization of the cooperative. This is a good momentum in the effort to develop and drive the national economy of one of its main pillars, that is the cooperative. The seriousness of the government to pay more attention to cooperative can be seen the Regulation of the Minister of Cooperatives and Small and Medium Enterprises in 2013 on Revitalization of Cooperatives.

Revitalization of cooperative emphasis on the return of the cooperative identity as bearers of the mandate of the members' welfare and also become a business institution based on the quality of governance, the participation of members, diversification of product and enhancing the competence of all members of the cooperative. (Regulation of the Minister of Cooperatives and SMEs: 2013). Revitalization means the process, ways and acts to empower something that was previously helpless. Simply, revitalization Cooperative interpreted as a series of activities undertaken to reorganize the institutional and strengthen the cooperative enterprises in accordance with the values and principles of cooperatives. The goal of the revitalization of the cooperative is to strengthen the position of the cooperative to become a healthy, strong, independent and tough enterprise to raise and move the potential economic, social and cultural (Regulation of the Minister of Cooperatives and SMEs: 2013).

\section{Participation of Cooperative Members}

Internal factors that play a role in the performance of the cooperative is the level of participation by members (Aini et al.: 2012; Aaron, et al: 2012; Ching Choo Huang et al: 2014). The higher the level of participation of members, then their contribution to the performance of the cooperative will be even greater. Therefore, the cooperative should always trying to build cooperation with the members, due to the unique position of members, which are as the owners and the customers of the cooperative as well. As the owner of the cooperative the members should support the organization's management and the cooperative capitalization, while as a customer, the member should be able to take 
benefit from the potential and services offered by cooperative. Cooperative enterprise is intended to meet the needs of members and thus, when members as consumers do not participate in the cooperative, the cooperative enterprise will have no economic value. Strong institutions and cooperative business is depend on the extent to which the member support them. The proposed hypothesis $(\mathrm{H} 1)$ is the participation of members (X1) effect on the strengthening of cooperative institutions and businesses/enterprises $(Y)$.

\section{The Competence of Human Resources}

Variable which is also important in strengthening the institutional and cooperative enterprise is the competence of human resources. Competence, according to Spencer and Spencer (1993) is the underlying characteristics of a person and related to the effectiveness of individual's performance on the job. Individual competence is something inherent that can be used to predict the performance.There are five characteristics that form a competence which are knowledge, skills, self-concept and values, personal characteristics and motives. The human resource's competency plays an important role in any organization (Bhatnagar, J and A Sharma: 2005; Kaplan, RS and D Norton: 2006). Business organizations are increasingly recognizing that human resources as an important factor in order to improve competitiveness and overall business performance.

Research done by Filsa and Wirda et al. (2016) mentioned that the managerial competencies have the positive impact to the competitive advantage. Whereas, while Nur Effendi (2015) explains that human resource development based on competency should be supported by hard learning. Kaplan and Norton (2006) mentioned that in the era of knowledge-based global economy, nearly $80 \%$ of the value of a company is derived from intangible assets such as human capital.That, any organization that wants to remain capable of performing in an increasingly competitive business environment, should have a reliable, capable, competent, and terrific human resources (Anoraga 2007). The proposed hypothesis $(\mathrm{H} 2)$ is competence of manager (X2) effect on strengthening the institution (Y) and enterprises (H3) of cooperative. Competence of marketers (X3) has also influenced on institutional strengthening and cooperative enterprises $(Y)$.
Based on the above description as well as the urgency of the implementation of the revitalization, so that strengthening cooperative institutions and cooperative enterprises is a requirement which have to be done promptly. The problem of this study is how to strengthen the institutional and cooperative enterprises and what is their impact on member assets. This paper will explore the link between the level of member participation and human resources' competencies to the strengthening of institutional and cooperative enterprises and their impact on member assets.

\section{Research Methodology}

Population in this research is human resources of saving and loan cooperative in Semarang city. Based on the evaluation report from the Department of Cooperatives and SMEs of Central Java Province on the health of cooperatives / saving and loan unit, in fourth quarter of 2015, the number of cooperatives recorded 81 units and spread across all districts in Kotamadia (city of) Semarang. Sampling is done gradually by using purposive sampling and stratified sampling method. Purposive sampling is a sampling based on certain criterias, so that the selected sample is relevant to the research design. Stratified sampling is sampling based on the existing strata.

Stages of customers sampling are as follows: (1) Of the 81 cooperatives in Semarang, the selected cooperative is cooperative of savings and loans, legal entities that have been operating for 5 years. The basis of the criteria is business continuity; (2) Cooperative selected is healthy cooperatives and fairly healthy cooperatives are (50\% for each of the category); (3) Determining cooperative customers from selected cooperatives in no.2. The selection of cooperative customers is based on long membership of at least 2 years; (4) The number of samples taken as many as 100 respondents. According to Uma Sekaran (2006), a sample size of more than 30 and less than 500 is appropriate for most studies.

The data needed are primary data and secondary data. Methods of data collection is by questionnaire and documentation. The questionnaire is designed with open and closed statement and/or question. The questionnaire is divided into two parts. The first part contains the question of indepth profiles of respondents in view of demographic 
factors (gender, marital status, education, income, length of work). The second section contains statements relating to institutional strengthening and cooperative effort and participation of cooperative members and human resources. The answer has been provided with five alternative answers using Likert scale (scale 1 if the answer strongly disagrees and scale 5 for strongly agreed). Documentation data which is secondary data obtained from the Office of Cooperatives and SMEs Semarang, data from Central Bureau of Statistic (BPS) and other publications that support the research.

Data analysis method that will be used in this research is logistic regression. The ChiSquare Hosmer and Lemshow test (Ghozali, 2006) is used to assess the feasibility of logistic regression model. This test is used to test the hypothesis: HO: There is no difference between the predicted classification with the observed classification or the model is feasible to use and $\mathrm{H} 1$ : There is a difference between the predicted classification with the observed classification or the model is feasible to use (goodness of fit).

\section{Overall Model Assessment.}

The overall assessment of the regression model uses the log-2 Likelihood value in which there is a decrease in the log-2 Likelihood value in second block compared to the first block, then the second model of the regression is better than the first one. In principle, logistic regression has a purpose to estimate the magnitude of the probability of certain events within a population as an exploration function.

Logistic regression is the part of regression analysis used when the dependent variable is a dichotomous variable consisting of two categories and is usually given the numbers 1 and 0 . The model used in logistic regression is: $\mathrm{Li}=\mathrm{Ln}(\mathrm{P} / 1-\mathrm{P})=\beta 0+\beta 1 \mathrm{X} 1+\mathrm{B} 2$ $\mathrm{X} 2+\beta 3 \mathrm{X} 3+\ldots . .+\beta \mathrm{n} \mathrm{Xn}$. where $\mathrm{Li}=$ response variable in this case is the role of cooperative $(1=$ healthy; $0=$ healthy enough $) ; \mathrm{BO}=$ constants; $\mathrm{B} 1=$ coefficient of predictor $1 ; \mathrm{Bk}$ $=$ coefficient of $\mathrm{k}$ predictors; $\mathrm{X} 1=$ predictor variable $1 ; \mathrm{Xk}=$ predictor variable $\mathrm{k}$.

\section{Description of Respondents}

The majority of respondents are female with marital status married. Viewed from the age, $27 \%$ of respondents aged $\geq 44.9$ years and $40 \%$ included in the productive age. Most respondents is high school graduated and $38 \%$ are in higher education. Many respondents work as private employees. Viewed from long-time members, $86 \%$ of respondents have joined cooperatives for more than 5 years. From the managerial position, the number of cooperative staff is 22 people $(61,11 \%)$ manager of 8 people $(22,22 \%)$ and management of 6 person $(16,67 \%)$. Viewed from the education level, the majority have been graduated from D3 S1 which is 32 people $(88,88 \%)$ people and only 4 people $(12,12 \%)$ from high school education. Duration of respondents' work are categorized into: 3 years - 5 years of 4 people; 5 years -10 years of 26 people and the remaining 6 people have joined the cooperative for more than 10 years.

Related to the consumption of cooperative products, the customers are active customers and users of cooperative products as it is seen from the number of members who use savings, time deposits and credit more than $50 \%$. Interesting reasons to use the products include administrative requirements, the interest rate offered, and the services provided. The prizes offered are not the main attraction because the respondents who voted for that reasons were below $50 \%$. The reasons for the use of savings, time deposits and credit are the increase in household assets such as for the purchase of home furnishings, the purchase of movable assets or home renovation.

\section{Assessing the Fit Model.}

The hypothesis proposed to assess the fit model is: Ho: Model fit with data and $\mathrm{Ha}$ : Model does not fit with data. To test the null hypothesis and the alternate hypothesis, $L$ is transformed into -2 log likelihood with degree of freedom $n-q$ where $q$ is the number of parameters. The output gives two likelihood -2Log values is one for models that only include constants and the second model includes constants and independent variables. The log-likelihood value of the model entering the constant is 138.269 having the Chi Squared distribution with df 99 (100-1) and in the model entering the constant and the free variable is 66.007 having the Chi Squared distribution with df 96 (100-4). The difference of -2Log likelihood value for model with constant and model with constants and free variable is 72.262 with df 3 (99-96) and this figure is statistically significant then the null hypothesis is not rejected and with the addition of free variable of Human Resources manager, marketing force and participation 
in model to fix fit model.

Tabel 1

Assessing the Fit Model

\begin{tabular}{cccc}
\hline Iteration & $\begin{array}{c}\text { 2 log } \\
\text { likelihood }\end{array}$ & $\begin{array}{c}\text { Coefficients } \\
\text { Contant }\end{array}$ \\
\hline Step 0 & 1 & 138.269 & .120 \\
& 2 & 138.269 & .120
\end{tabular}

Source: Data Processing Result 2016

\begin{tabular}{cccc}
\hline Step1 & $\begin{array}{c}-2 \text { Log } \\
\text { likelihood }\end{array}$ & $\begin{array}{c}\text { Cox \& Snell } \\
\text { R Squared }\end{array}$ & $\begin{array}{c}\text { Nagelkerke } \\
\text { R Squared }\end{array}$ \\
\hline 1 & 66.007 & .515 & .678 \\
\hline
\end{tabular}

Source : Data Processing Result 2016

Seen from the output value of Cox and Snell $R^{2}$ of 0.515 and Nagelkerke $R^{2}$ of 0.687 , which means variability of dependent variable which can be explained by the variability of independent variable equal to $68,7 \%$. Hosmer and Lemeshow test results, Chi Squared value 9.108 with a significance value of $0.333>$ from 0.05 which means no difference between the predicted classification with the observed classification or the model simply explains the data. This means that logistic regression models can be used for further analysis.

Table 2

Assesing The Fit Regression Model (Hosmer and Lemeshow Test)

\begin{tabular}{cccc}
\hline Step & Chi-Square & df & Sig \\
\hline 1 & 9.108 & 8 & .333 \\
\hline \multicolumn{4}{c}{ Source : Data Processing } \\
\hline
\end{tabular}

Analysis of the influence of predictor variables on the variables response can be seen in the table below. Testing through Chi Squared with $\mathrm{df}=\mathrm{k}-1$ where $\mathrm{k}$ is the number of predictor variables.

Table 3

Omnibus Test

\begin{tabular}{rccc}
\hline & Chi-Square & df & Sig \\
\hline Step & 72.263 & 3 & .000 \\
Step 1 Block & 72.263 & 3 & .000 \\
Model & 72.263 & 3 & .000 \\
\hline
\end{tabular}

Source : Data Processing Result 2016

Chi Squared table df 3 at $95 \%$ confidence level $(a=5 \%)$ is 5.99 . The result shows that Chi Square value> Chi Square table value is 72.263> 5.99 so it can be concluded that predictor variable has an effect on institutional strengthening and cooperative enterprises.

Based on the Wald test of the Logit model described in the table 4, it appears that the factors that affect the institutional strengthening and cooperative effort with the level of $a=5 \%$ is the participation and human resources factors with a significance level of each 0.000 . While the factor that does not significantly affect is the marketer.

Table 4

Wald Statistic Test Values

\begin{tabular}{cccc}
\hline & B & Wald & $\begin{array}{c}\text { Sig } \\
\text { Exp(B) }\end{array}$ \\
\hline Participationi & 1.805 & 14.305 & .000 \\
Step 1 HR & .260 & 21.438 & 6.083 \\
& -030 & .049 & .000 \\
Marketer & 9.349 & 2.647 & 1.296 \\
Constant & & & .824 \\
& & & .970 \\
& & & -104 \\
\hline
\end{tabular}

Source : Data Processing Result 2016

From the logit model obtained, it can be seen that the log of odds of a healthy cooperative is positively related to the participation of members and human resources of the cooperative manager. In a healthy/fairly healthy cooperative, the increase of every unit of participation will increase the log odds of the cooperative (will be healthy) with the number of 1,805 . If another factor is constant, then the log of odds of the cooperative (will be healthy) would increase of 0.260 , if there is an increase of one unit of human resources.

\section{Relation between member's partici- pation with institutional strengthen- ing and cooperative enterprise.}

The relationship between odds and independent variables is as follows: The odds ratio of participation factor is $>1$ is 6,083 . If the other factor is constant, then the healthy cooperative odds will increase to 6,083 of the cooperative healthy enough for any increase in perceptions of member participation. In other words, the participation of members has a tendency to achieve a healthy cooperative 6,038 times greater than a fairly healthy cooperative. This is because the cooperative belongs to members then the performance of the cooperative is very dependent on the members. The uniqueness of the cooperative also lies in the function of the member that is as the owner and the service user of the cooperative. Owners who work optimally and users who utilize cooperative services optimally would increase the cooperative performance. 
The results of this study is in accordance with the opinion of Ropker Jochen (2003) which stated that the participation of members will support the success of cooperatives that are reflected in the performance of cooperatives. One of the effectiveness of member participation is seen from the level of benefit received. The results show that $81 \%$ of respondents have joined the cooperative for more than five years. This shows that members of the cooperative have felt the benefits received from the cooperative. More data related to the level of participation can be seen in the table below:

Table 5 Member Participation

\begin{tabular}{|c|c|c|c|c|}
\hline & \multicolumn{3}{|c|}{ Participation } \\
\hline & & High & Medium & Low \\
\hline Marital & Married & 25 & 25 & 21 \\
\hline Status & Unmarried & 11 & 10 & 8 \\
\hline \multirow[t]{7}{*}{ Education } & Junior High & 8 & 5 & 0 \\
\hline & school & 20 & 22 & 7 \\
\hline & Senior High & 6 & 13 & 2 \\
\hline & School & 6 & 6 & 5 \\
\hline & $\begin{array}{l}\text { 3-year } \\
\text { diploma }\end{array}$ & & & \\
\hline & Bachelor & & & \\
\hline & degree & & & \\
\hline \multirow[t]{2}{*}{ Gender } & Male & 8 & 13 & 8 \\
\hline & Female & 6 & 33 & 32 \\
\hline \multirow[t]{3}{*}{ Occupation } & Government & 4 & 8 & 1 \\
\hline & employees & 21 & 25 & 8 \\
\hline & $\begin{array}{l}\text { Private } \\
\text { employees } \\
\text { Entrepreneur }\end{array}$ & 15 & 13 & 5 \\
\hline \multirow[t]{6}{*}{ Age } & $25-34,9$ & 2 & 3 & 1 \\
\hline & years & 5 & 5 & 11 \\
\hline & $35-44,9$ & 19 & 10 & 11 \\
\hline & years & 10 & 17 & 6 \\
\hline & $\begin{array}{l}45-54,9 \\
\text { years }\end{array}$ & & & \\
\hline & $\begin{array}{l}55-64,9 \\
\text { years }\end{array}$ & & & \\
\hline \multirow{3}{*}{$\begin{array}{l}\text { Long } \\
\text { been a } \\
\text { member }\end{array}$} & $<5$ years & 11 & 4 & 0 \\
\hline & $5.9-9,9$ & 18 & 20 & 2 \\
\hline & $\begin{array}{l}\text { years } \\
10-14.9 \\
\text { years }\end{array}$ & 11 & 18 & 12 \\
\hline
\end{tabular}

Source : Data Processing Result 2016

In the table above it appears that participation rates are divided into high, medium and low participation. Judging from the marital status, the percentage of those who married at high, medium and low participation levels is similar. While viewed from the type of education, members with high school education have high participation of $20 \%$, and $22 \%$ of medium participation. Women tend to have moderate and low levels.
In relation to the work of members, private employees participate highly in cooperative activities compared to civil servants or entrepreneurs. Based on the data processing, gender and long time membership have a correlation to the level of participation. Contingency coefficient between participation with the long time members and the gender of 0.436 and 0.255 respectively. This shows that the correlation between variables is low.

\section{Relation between management with institutional strengthening and cooperative enterprises}

Like any other business units, cooperatives are not only compete with other cooperatives, but also with other financial institutions, both banking and non-banking. Along with the increasingly competitive competition and rapid change ofscience and technology, then the cooperative is in need for competent human resources in order to achieve organizational goals and targets set. Cooperative human resources include board members, supervisors and members. Although their roles are very different, the performance of cooperatives is the result of the performance of all members and managers together in accordance with the quality and standards set. Therefore, cooperatives require human resources who have unique skills and capabilities that are in accordance with the vision and mission of the cooperative concerned.

The results show that the odds ratio of Human Resources factor is $>1$ is 1.296. If other factors remain, then the healthy cooperative odds will rise of 1.296 from the fairly healthy cooperative for any increase to the perception of human resources manager. In other words Human Resources Cooperative has a tendency to achieve a healthy cooperative for 1,296 times bigger than fairly healthy cooperative. This is because Human Resources is a very vital asset for cooperatives. Experience, educational background, self-competence is very necessary in the management of cooperative business.

Marketers who initially suspected to affect the tendency of healthy cooperatives were from the analysis of logistic regression results found out there was not enough evidence to show that these factors significantly affect the performance of cooperatives. Marketers do not show a significant influence because the turnover of marketers is quite high (interview results). 
The frequency of marketers' succession will affect the performance of the cooperative. Turn over is high because in general, marketers are not able to meet the target. This makes the marketing force does not affect the strengthening of institutional and cooperative enterprises.

\section{The Impact Toward Member Assets}

Assets of members will be seen from financial capital and human capital. The result of financial capital test and human capital before and after become a member of cooperative is valid and reliable. This is indicated by Cronbach Alpha value for financial capital before and after become a member is 0.605 and 0.620 , while for human capital is 0.608 and 0.614 . Wilcoxon Signed Rank Test seen in the table below:

Table 6 Wilcozon Signed Rank Test

\begin{tabular}{ccc}
\hline & $\begin{array}{c}\text { Financial Capital } \\
\text { After- } \\
\text { Financial Capital } \\
\text { Before }\end{array}$ & $\begin{array}{c}\text { Human } \\
\text { Capital } \\
\text { After - } \\
\text { Human } \\
\text { Capital } \\
\text { Before }\end{array}$ \\
Z & $-6,062^{\mathrm{b}}$ & $-2,015^{\mathrm{b}}$ \\
$\begin{array}{c}\text { Asymp. } \\
\text { Sig. } \\
\text { (2-tailed) }\end{array}$ &, 000 &, 044 \\
\hline & Source : Data Processing Result 2016
\end{tabular}

Based on the above results, it is known that there is a significant difference between financial capital and human capital before and after becoming a member of the cooperative. This is indicated by a significance value of $0.000(<0.05)$. The situation shows that cooperatives have a role to the members. After becoming a cooperative member, there are improvements in financial capital as they have savings, facility to get credit which generally used to repair houses, buy transportation vehicles, buy household appliances while on the side of human capital, cooperative credit is often used for school or college entrance.

\section{Conclusions}

In order to strengthen the institutional and cooperative enterprises, the competency of human resources cooperative factor plays a meaningful role. Competent human resources are able to improve the performance and competitiveness of cooperatives. For the competence of human resources, it is necessary to improve the IT field because this has become the demands of the times. In addition to human resources, other factors that influence the institutional strengthening and cooperative enterprises is the participation of members. The more members of the cooperative consume/ use cooperative products, the cooperative business will be increasing. In order to increase the participation of members, the element of service to customers needs to be improved by providing product diversification such as arisan saving. This is to make customers get used to regularly save their money and strengthen the relationships between members. Besides, it provides deposit transfer facility to bank account so that customers would have no difficulties in withdrawing their money through ATM of Bank.

The impact of cooperatives on member assets is evident from financial and human assets. After becoming a member of the cooperative, members have an improvement in financial capital as they have savings, the ease of getting credit that is generally used to repair homes, buy transportation vehicles, buy household appliances while on the human capital side, credit cooperatives is often used to pay fee of school or college entrance.

\section{References}

Amira Y. Badri. (2013). The Role of Microcredit System for Empowering Poor Women, Journal of Management and Science.Developing Country Studies. Vol. 3 No.5.

Aini,Y.M.,Hafizah,H.A.K.,Zuraini,Y. (2012). Factors Affecting Cooperatives' Performance in Relation to Strategic Planning and Members' Participation,Procedia-Social and Behavioral Science,65,100-105.

Anoraga, P. (2007). Pengantar Bisnis: PengelolaanBisnisdalam Era Globalisasi, Jakarta, Rineka Cipta.

Awojobi,Omotola and Murad Bein.(2011). Microfinancing for Poverty Reduction \& Economic Development: A Case for Nigeria. MPRA

Bhatnagar, J dan A Sharma. (2005). The Indian Perspective of Strategic HR Roles and Organizational Learning Capability, Int. J. Hum. Res. Manage., Vol. 16, No. 9, pp. 1711 - 1739.

Durrani, Muhammad Kashif Khan, Abid Usman, Muhammad Imran Malik, Shafig 
Ahmad.(2011). Role of Micro Finance in Reducing: A Look at Social and Economic Factors, International Journal of Business and Social Science.Vol.2 no. 21 November.

Efendi, Nur. (2015). Pengembangan Sumber Daya Manusia Berbasis Kompetensi di Kantor Pemerintah Kota Bandar Lampung,Jurnal Mimbar,Vol.31,No.1.

Ghozali, I. (2006). Aplikasi Analisis Multivariate dengan Program Aplikasi SPSS. Cetakan ke Empat, Semarang, Badan Penerbit Ilmu Ekonomi UniversitasDiponegoro.

Huang, Ching Choo ,Zazale,S., Othman, R., Aris ,N.A., Ariff, S.M.M.(2013). Influence of Cooperative Members' Participation and Gender on Performance, Journal of Southest Asian Research. Vol.2015.

Kaplan, RS dan D Norton (2006), The Balance Scorecard: Translating Into Action, Boston, Harvard Business School Pres.

Majee, Wilson and Ann Hoyt.(2011). Cooperatives and Community Development: A Prespektip on the Use of Cooperatives in Development, Journal of Community Practice, 19, pp.48-61.

Omonona B.T.(2011). Poverty and Its Correlates among Rural Farming Household in Kogi State, Nigeria.

Ropker, J. (2003). Ekonomi Koperasi. Teori dan Manajemen, Jakarta, Salemba 4.

Sarumathi S., and K. Mohan. (2011). Role of Micro Finance in Women's Enpowerment (An empirical study in Pondicherry regional rural SHG's), Journal of Management and Science, Vol.1 No.1 September.
Sekaran,U. (2006). Metodologi Penelitian untuk Bisnis, Edisi 4, Buku 1, Jakarta: SalembaEmpat

Situmorang, Johnny $\mathrm{W}$ and Saudin Sijabat. (2011). Koperasi dan Penanggulangan Kemiskinandi Indonesia. Tinjauan Probability Tingkat Keanggotaan Koperasi dan Kemiskinan Propinsi, Jurnal Pengkajian Koperasi dan UMKM Vol 6 September.

Sukijo.(2008).Membangun Citra Koperasi Indonesia, Jurnal Ekonomi dan Pendidikan. Vol 5 no.2D.

Spencer, Lyle and Signe Spencer. (1993). Competence at Work, Canada, Jhon Wiley \&Sons, Inc.

Swasono, S E. (2012). Koperasi dan Ekonomi Humanistik, Kompas12 Juli.

Swasono, S. E. (2012). Kooperativisme dan Revitalisasi Koperasi, Warta KUMKM, Edisi $1 \mathrm{~F}$.

Widiyati, S. (2012). Analisis Peluang Koperasi Dalam Pengetasan Kemiskinan, Jurnal Keuangan dan Bisnis. Vol 1 no.1.

Wirda,Filsa, Tuti Azra and Herizan. (2016a). The Influence of Managerial Competency and External Enviroment on the Competitive Advantage of a Creative Industries in West Sumatra. Jurnal Mimbar,Vol.32,No.1,pp.126-138.

Wirda,Filsa, Tuti Azra and Herizan. (2016b). KoperasiBaruMenyumbang 2 Persen PDB. (http://www. suaramerdeka.com/v1/index.php/read/ cetak/2009/07/11/72018/Koperasi-BaruMenyumbang-2-Persen-PDB). Download 8 July 2015. 